\title{
Výuka v př́írodě: módní hit či smysluplná výuka?
}

\author{
Jaroslava Ševčíková
}

Univerzita Palackého v Olomouci, Pedagogická fakulta, Ústav pedagogiky a sociálních studií

\author{
Redakci zasláno 28. 9. 2020 / upravená verze obdržena 2. 2. 2021 /
}

/ k uveřejnění přijato 2. 2. 2021

\begin{abstract}
Abstrakt: Studie se zabývá společensky frekventovaným tématem, paralelním k probíhající odborné diskusi, a to výukou přírodopisu na druhém stupni základní školy v terénu, v př́rodě. Cílem v této studii bylo zjistit vztah učitelů a žáků k této výuce. Jde o reakci na problém vzniklý direktivním nařízením vedení (některých) škol vyučovat př́rodopis mimo třídu, venku, což není vždy v souladu s učitelovým pojetím výuky. Do kvalitativního výzkumu se zapojilo dvacet devět učitelů přírodopisu z dvaceti sedmi základních škol a třicet osm žáků ze dvou tříd různých škol. Sběr dat byl realizován metodou autonomního psaní, kdy jedinec popisuje i hodnotí svou zkušenost bez zásahu badatele, a doplňkově prostřednictvím rozhovorů na dané téma. Výzkum probíhal v přirozeném prostředí, v praxi škol. Data jsou výsledkem subjektivní reflexe jednotlivců a byla podrobena interpretativní fenomenologické analýze, texty byly děleny na smysluplné významové jednotky a ty pak seskupovány, a v nich byly vyhledávány opakující se vzorce. Následná interpretace byla realizována v rámci spolupráce respondentů a badatele přístupem collaborative accounts. $\mathrm{Z}$ výzkumu vyplynulo, že výuka přírodopisu v přírodě dává zúčastněným vyučujícím i žákům smysl pouze v př́ípadě, že se s ní ztotožní a jsou na ni připraveni, že je zvládnuta nejen odborně obsahově, ale také organizačně.
\end{abstract}

Klíčová slova: výuka, vyučování, učení, přírodopis, základní vzdělávání

Výchova v přírodě patří $\mathrm{k}$ aktuálně diskutovaným tématům, a to zejména výchova dětí a mládeže v době vědotechniky, kdy dochází k odklonu od přírody a orientaci na umělé systémy (Kot’a, 2012). Předložená studie se zabývá užší částí výchovy, výukou přírodních věd, a to mimo třídu. Kdy je vhodné, aby bylo opuštěno prostředí školní třídy a výuka se přesunula do terénu? A má to př́ínos pro učení žáků, či je preferován přínos jiný? Má smysl vyučovat v terénu obsahy, které s prostředím nesouvisí, neměla by volba prostředí mít vazbu na metody, cíle i výstupy výuky?

Kontext celospolečenských změn po tzv. sametové revoluci a školská reforma na počátku jednadvacátého století přinesly do oblasti školství na jedné 
straně jisté napětí a na straně druhé velké uvolnění a otevřenost škol směrem k laické veřejnosti (Štech, 2000), kdy právo vyjadřovat se k výchově a vzdělávání má každý, at' už odborník, laik či účastník výchovy (srov. Šíp, 2019, s. 20). Můžeme respektovat, že k výuce ve škole se dnes vyjadřují kromě odborníků a aktérů výuky také rodiče, politici a novináři. Problém je, když se tato vyjádření vydávají za odborné argumenty - možná proto, že do školy každý kdysi chodil, a tak se cítí být odborníkem. Pokud je těmto slovům nasloucháno, může být podle nich upravován a organizován výchovně-vzdělávací proces v konkrétních školách, zejména v touze vyhovět a nemuset obhajovat profesionálně nastavené procesy. Na základě toho je často vyvíjen na jednotlivé učitele tlak ke změně, se kterou se profesně neztotožňují, ale pod tlakem podléhají (Vaštatková \& Prášilová, 2007). Obava z konfrontace a nutnosti obhajovat svá přesvědčení je vysoká.

V názvu této případové studie jsem se záměrně uchýlila k neodborné, až publicisticky burcující terminologii, protože také o tom předložená studie je. O neodborném vyjadřování, o prázdných frázích a odborně nepodložených deklaracích. Zaměřuji se na oblast výuky př́rodopisu v základní škole, kde se to popsanými jevy jen hemží. Jedna z učitelek přírodopisu dostala od ředitele nekompromisní příkaz: „Učte přírodopis zážitkovou pedagogikou!“ Jak a proč dochází v našich školách k tomuto terminologickému kutilství (Štech, 1994) a jaké dopady to má na učitele? Jak se učitel vyrovnává s takovým nařízením? A jaká bude výuka realizovaná pod tlakem?

Toto parciální šetření je součástílongitudinálního výzkumu s názvem Vybrané aspekty formování profesního přesvědčení začínajících učitelů v rámci kvalitativní strategie, která objasňuje aspekty formování epizodní složky profesního přesvědčení učitelů (Ševčíková \& Plischke, 2020). Výše zmíněná situace byla jednou z epizod (profesních situací) řešených výzkumem na základě (sebe)reflexe (Slavík \& Čapková, 1994; Švec, 1997). Učitelce bylo direktivně nařízeno změnit své pojetí výuky (Kalhous \& Obst, 2002; Lukášová, 2015) s odůvodněním nadřízeného, že „jsou to moderní trendy a zřizovatel i rodiče si je žádají a je třeba, za každou cenu, začlenit je do výuky“. Realizace takovéto výuky se pak učiteli jeví jako problémová profesní situace tak významná, že má vliv na formování jeho profesního přesvědčení. Učitel obtížně mění své pojetí výuky, tedy to, jak ji plánuje, realizuje i hodnotí (Mareš, 1990a, 1990b; Mareš et al., 1996), pokud ve změně nevidí smysl (Frankl, 2006). Proto jsem se v empirickém šetření zaměřila na situaci, kdy je učiteli nařízeno změnit pojetí výuky, a výsledky zde předkládám. 


\section{Teoretická východiska}

Realizace této studie byla inspirována, kromě výše uvedeného, také výzvou vědeckého časopisu Pedagogická orientace k zasílání př́íspěvků o výchově $\mathrm{v}$ př́rodě. Ta má nepopiratelně v našem prostředí bohatou tradici, a to zejména v oblasti rozvoje volnočasových aktivit dětí a mládeže. Rozvíjí se ale i v oblasti výuky ve školách, především v přírodovědně orientovaných předmětech. Je to, co je vydáváno za výuku v př́rodě, skutečně plnohodnotnou výukou v komplexním kurikulárním a didaktickém rámci?

Protože pedagogická terminologie není vždy v souladu s běžnými hovorovými výrazy a často je v dílčích aspektech odlišná i dle reflektované pedagogické teorie daného odborníka, vymezím při shrnutí současného stavu problematiky terminologické prostředí této studie. Kurikulum př́rodopisu základní školy (ZŠ) je shrnuto v Rámcovém vzdělávacím programu pro základní vzdělávání (RVP ZV, 2017) v rámci vzdělávací oblasti Člověk a př́roda na 2. stupni ZŠ a jednotlivé školy si zpracovávají své školní vzdělávací programy, které jsou závazné. Vzdělávací obsah školní výuky je definován očekávanými výstupy a doporučeným učivem. Vše další je v režii školy a učitele, odborníka na danou problematiku. Ten, díky svým profesním kompetencím a didaktickým dovednostem, připravuje, organizuje a řídí výuku (Obst, 2017, s. 83), přičemž výuka je společný proces interakce učitele, který vyučuje, a žáků, kteří se učí (Maňák \& Švec, 2003). Učitel volí učivo i další prostředky na základě cíle výuky. Učivo zpracovává didaktickou transformací (Kropáč \& Kropáčová, 2006), vhodně volí strukturu, organizaci, metody i formy práce, prostředí výuky i pomůcky (Kalhous \& Obst, 2002), které vycházejí z jeho pojetí výuky (Mareš, 1990a, 1990b), typických až individuálně originálních přístupů k profesi a jejímu naplňování, které jsou mu vlastní a relativně ustálené.

Výuka přírodopisu je v posledních letech v odborné komunitě intenzivně diskutována, zejména od doby, kdy se téma tzv. přírodovědné gramotnosti objevilo v Plánu hlavních úkolů České školní inspekce pro školní rok 2018/2019 (2018). Již delší čas se ale ozývají hlasy, které upozorňují na problémy výuky př́rodopisu (Jáč et al., 2019, s. 9) a dokládají, že žáci nemají o přírodopis zájem. Výsledky šetření PISA (Blažek et al., 2018) potvrzují zhoršování výsledků v přírodovědné gramotnosti. Odborníci hledají cesty (např. Jáč et al., 2019; Papáček et al., 2015; Slavík et al., 2017), ale laická, nepedagogická veřejnost, jak se zdá, má jasno. Díky finanční podpoře vzniklo několik projektů zaměřených na výuku o přírodě v př́rodě s tím, že úspěch je už to, když jsou děti venku. 
Pojem profesní situace v této studii definuji jako časově ohraničenou situaci, která je souhrnem okolností, jevů, které mají vazbu na realizaci profese (Slavík et al., 2017, s. 300). Problémovou profesní situaci zde definuji jako profesní situaci, která se jeví nová, obtížná a nejasná (Maňák \& Švec, 2003, s. 115), v tomto př́ípadě jde o problém vzniklý direktivním nařízením vedení školy, které není v souladu s učitelovým pojetím výuky.

0 výuce $v$ prŕrodě budu zde $\mathrm{z}$ praktických důvodů hovořit také jako o výuce venku, tedy mimo standardní třídy školní budovy, a to proto, že se cíleně chci vyhnout definování pojmu prŕroda, v duchu otázek: Je př́roda i rostlinstvo ve skleníku, záhonek před školou či městský park? Výuka venku je zde definována jednak jako aplikace praktických metod poznávání přírody (výstupy dle RVP ZV, 2017), které označuji jako výuku v terénu, jednak jako výuka obsahů přírodopisu bez vazby na konkrétní přírodní prostředí (např. výuka genetiky, mitózy atd.), kdy žák nemůže vyučované jevy pozorovat.

Pokud se vrátím k požadavku výše citovaného ředitele, který pronesl: „Učte přírodopis zážitkovou pedagogikou!“, je třeba se ptát, co bylo myšleno „zážitkovou pedagogikou“. Pojem, zde použitý zjevně nesprávně (srov. Jirásek, 2016), je v této oblasti velmi frekventovaný, at' už v tomto sousloví či ve vazbě „zážitková výchova“ či „zážitkové učení", jak uvádí Dočekal (2012), který upozorňuje, stejně jako výše Jirásek, na nejednotnost a neustálenost užívání pojmů. Ty nejsou v pedagogické terminologii dosud jednotně etablovány a jsou využívány v různých kontextech podle zaměření autora, a ani odborníci se na jejich výkladu neshodnou. 0 to obtížnější je moje situace, protože pro výzkum bylo nutné pojem vymezit tak, aby byl jednoznačně pochopen učiteli (respondenty) z praxe. Volím vymezení pojmu zážitek jako reflektovaný prožitek či prožitky, to, co bylo osobně prožito a zpětně promýšleno, i s tím rizikem, že vyvolám nelibost některých odborníků. V kontextu výuky a učení zde zážitek není automaticky součástí žákova učení (srov. Strouhal, 2013). Součástí učení se stane, jen když bude dostatečně vyhodnocen, reflektován a zpracován mentálními procesy žáka prostřednictvím myšlenek vyjádřených ve slovech a transformován ve vědomosti, dovednosti či postoje, tedy složky učiva (Kalhous \& Obst, 2002, s. 126). Proto bych doporučovala raději používat $\mathrm{v}$ rámci výuky a výukových situací pojmy takto: výuka pomocí zážitku, výuka se zážitkem, učení pomocí zážitku, aby bylo jasné, že osamocený, nereflektovaný zážitek negarantuje záměrné a cílené učení, ale může být, pokud je s ním ve výuce vhodně nakládáno, jeho předstupněm, inspirací i motivací, přičemž na zážitek zde není kladen nárok excelentnosti ani výjimečnosti. 


\section{Metodologie výzkumu}

Výzkum byl realizován v kvalitativním designu. Cílem bylo zjistit vztah učitelů a žáků $\mathrm{k}$ výuce venku. Byly řešeny následující výzkumné otázky: Jaký je vztah učitelů přírodopisu 2 . stupně ZŠ k výuce venku, mimo školní lavice. Liší se v případě, že se pro tento přístup rozhodnou učitelé sami a v případě, že je jim nařízen?

Sběr dat probíhal metodou autonomního psaní, volných odpovědí na písemně zadané otázky s doplňujícím rozhovorem na dané téma u dvou typů účastníků školní výuky: učitelů a žáků. U obou skupin proběhl sběr dat dvakrát: poprvé když učitelé deklarovali vstupní, z jejich pohledu negativní zkušenost $\mathrm{s}$ př́ḱkazem vyučovat venku obsahy, které s výukou v terénu nesouvisí, a podruhé přibližně půl roku po realizaci vybraného vzdělávání učitelů orientovaného na výuku venku, mimo školní lavice, v rozmezí roku až roku a půl po prvním dotazování.

Data byla zpracována interpretativní fenomenologickou analýzou se záměrem rozkrýt vztah obou skupin $\mathrm{k}$ danému fenoménu - k výuce přírodopisu venku. Byly vyhledávány opakující se vzorce výroků.

Výzkumný vzorek tvořilo dvacet devět učitelů př́rodopisu z dvaceti sedmi základních škol a třicet osm žáků ze dvou tříd různých škol. Učitelé absolvovali Studium $k$ výkonu specializovaných činností v oblasti environmentální výchovy v rozsahu 250 hodin (např. https://www.lipka.cz/vzdelavani-koordinatoru); zde byli získání pro zapojení do výzkumu. Toto studium je akreditováno Ministerstvem školství, mládeže a tělovýchovy České republiky, většina učitelů (kromě dvou) uvedla, že zároveň absolvovali i další kurzy pro pedagogy či školení pro dlouhodobé aktivity s žáky ve výuce, konkrétně (řazeno dle názvu instituce): Výuka v terénu, Hurá z lavic (https://www.chaloupky.cz/), Repetitorium terénní přírodovědy (www.lipka.cz), Kurz k př́rodním zahradám (http://www.liska-evvo.cz/), blíže neidentifikované školení k přírodním zahradám (https://slunakov.cz/), Ekoškola, Les ve škole, Globe, Učíme se venku (http://terezanet.cz/cz), blíže neidentifikovaný pobytový vzdělávací program v Hostětíně (www.veronica.cz).

Fenomén výuky mimo třídu byl analyzován z perspektivy aktérů a závěrečná interpretace, i při snaze o zobecnění, se stále snaží udržet spojení mezi zdroji dat a jejich interpretací. K účastníkům výzkumu i zpracování dat bylo přistoupeno záměrně $\mathrm{v}$ tzv. přístupu spolupráce - collaborative accounts 
(Švařriček, 2007, s. 130), který je založen na aktivní spolupráci mezi výzkumníkem (mnou) a účastníky výzkumu. Byla jsem lektorkou výše uvedených vzdělávacích programů a s respondenty-učiteli jsem opakovaně, více než rok, spolupracovala.

Otázky pro učitele zněly: Vyučujete př́rodopis venku, v terénu, v prrírodě, tedy mimo školní třídu? Pokud ano i pokud ne, uved'te prosím Vaše hlavní argumenty proč, uved'te, proč jste s tím začali a kdy. Inspirovali jste se nějakou koncepcí či strategií či organizací - ve smyslu tzv. zážitkové pedagogiky, lesní pedagogiky, programu učíme se venku, aktivit les ve škole či vlastní strategie? Uved'te její hlavní klad. Jak stanovujete cíl takové výuky? Otázka pro žáky zněla: Výuka př́rodopisu venku - zažili jste ji? Pokud ano, jaké byly její klady a jaké zápory? Popište je.

\section{Výsledky výzkumu}

Respondenti byli do výzkumu zařazeni na základě souhlasu a toho, že deklarovali reflektovanou problémovou profesní situaci (epizodu), vyplývající z nařízení vedení školy či zřizovatele, aby vyučovali venku i obsahy, které s tímto prostředím nesouvisí. Z pokynů, které zazněly, uvádíme např::

Učte přírodopis zážitkovou pedagogikou! Jsou to moderní trendy a zřizovatel i rodiče si je žádají a je třeba, za každou cenu, začlenit je do výuky.

Př́rodopis se musí učit venku, máme novou učebnu, je třeba dokladovat její využití, nemůže tam chodit jen družina.

Nabídněte žákům atraktivní přírodopis.[...]

V květnu a červnu a pak v záŕí a ř́jnu budete aspoň každou druhou hodinu s žáky v prŕrodopise venku [...] apod.

(citace z dat, výroky uváděné učiteli)

Z doplňkových rozhovorů vyplynulo, že pokyny vedení škol byly iniciovány zejména tím, že školy získaly granty a dotace na př́rodní zahrady a př́rodní učebny, na rozvoj přírodovědné gramotnosti a environmentální výchovy, včetně studia koordinátorů EVVO, a to hlavně v období realizace Šablon II (Přehled šablon ..., 2018, s. 21), které byly ve variantě $g$ - polytechnické vzdělávání mimo jiné zaměřené na prrírodovědnou gramotnost, badatelskou 
výuku, popularizaci přírodovědného a environmentálního vzdělávání a motivaci žáků k technickému a přírodovědnému vzdělávání.

Učitelé zapojení do výzkumu předtím mimo třídu nevyučovali, kromě záměrně plánovaných terénních exkurzí a vycházek s praktickým poznáváním organismů a prostředí. Jak uvádějí, nebyli na to připraveni, intenzivní realizace výuky mimo třídu jim byla přikázána dřív, než byli proškolení a než si stačili uzpůsobit své pojetí vyučování a výuky. Sběr dat probíhal před proškolením učitelů a podruhé po něm. Nejprve shrňme výsledky získané před proškolením učitelů.

Hlavní argumenty, proč vyučovat venku, můžeme shrnout pod výroky (vzorce výroků):

- žákům se (asi) lépe propojí učivo se skutečnými přírodními objekty, zjistí, že to není jen teorie;

- žáci získají (asi) motivaci ke studování přírody (bez bližší specifikace);

- učitel může teoretické koncepty ihned ilustrovat přírodním děním;

- změna prostředí může zvýšit zájem o výuku;

- musíme dokladovat činnost v rámci finanční dotace.

Naopak, hlavní argumenty proč venku nevyučovat, byly zastoupeny více a daly se roztř́ídit na bezpečnostní a organizační rizika. Zde uvádíme vzorce výroků:

Z bezpečnostních rizik to byly zejména obavy: „o zdraví žáků, kteří trpí alergiemi, respiračními potížemi i jistou neobratností, která při pohybu v terénu může vyústit v úrazy". Tvrzení učitelé často ilustrovali konkrétními př́́klady. Také nedostupnost WC a umyvadla s vodou se jevila jako ohrožující.

Z organizačních důvodů šlo o obavy:

- „ze ztráty času při přesunech“ - méně výrazná se tato obava jevila při přesunu na školní zahradu či do učebny vedle budovy školy, jako neuskutečnitelná $\mathrm{v}$ jedné vyučovací jednotce $\mathrm{z}$ časových důvodů se jevila výuka vycházkou v terénu;

- „z prostředí bez tabule a žákovských stolů (podložek) pro zápis a nepohodlí při využití učebnic a jiných pomůcek, které se mohou poškodit“; 
- „z (ne)udržení pozornosti žáků - když jsou venku, v novém prostředí, bude zřejmě mnoho jevů vyrušovat, a to jak akustických, tak vizuálních“;

• „z neuhlídání kázně“;

- „z nemožnosti udržet normy světelné, tepelné, popř. z prašnosti“;

- a také z toho, „že někteří žáci, ač budou/jsou upozorněni, nepřizpůsobí oděv a obuv výuce mimo třídu a pak, například při ušpinění oděvu, dochází ke konfliktům nejen s žáky, ale i rodiči“.

Ke koncepcím (Maňák \& Švec, 2003, s. 9) a strategiím výuky venku se učitelé v prvním šetření př́liš nevyjadřovali. Expresivně se vyjádřila jedna učitelka:

Nebudu nikomu dělat šaška, na poznávačku chodím s žáky ven už deset let, připravím se na to, vyžádám delší časovou dotaci, ale vést výuku teorie ve čtyřicetiminutovce venku, ke které potřebujeme já i žáci pomůcky, je holá blbost, a jestli jim jde o to [zde myšleno vedení školy], aby se děcka proběhla, aby si poskočili a nadechli se vzduchu, tak to mají dělat doma s rodiči nebo v kroužku nebo o přestávce. Moje výuka takové cíle hodiny neuznává!

Vyjádření, které se v mírných obměnách demonstruje i v dalších výpovědích, naznačuje obavy učitelů, že tím, proč je výuka venku vyžadována, je odklon „od řádné školní výuky a př́́klon k zábavě, k prostému zážitku“. Zda to tak skutečně bylo či je, třeba jen v malém množství popsaných př́ípadů, může být otázkou do diskuse, nicméně navodilo to u učitelů obavy.

V druhé části výzkumu, při sběru dat poté, co učitelé prošli školením institucí zabývajících se vzděláváním pedagogů ve výuce v přírodě (viz výše), došlo $\mathrm{k}$ výrazným změnám $\mathrm{v}$ oblasti argumentů, proč mimo třídu, venku, vyučovat i obsahy přímo nenavázané na učivo pozorovatelné $\mathrm{v}$ daném prostředí (např. venkovní učebna, školní zahrada). Výroky po zpracování interpretuji prostřednictvím vzorců, vzorových výroků, na kterých se respondenti shodli a utř́́dili je do tří oblastí:

- orientace na učivo: vznik, vývoj a rozmanitost, projevy života, tu je možno okamžitě dokládat, jen když se kolem sebe rozhlédneme, totéž k učivu nerosty a horniny, půdy, počasí, bezobratlí, rostliny, houby atd.;

- orientace na výstupy, cíle výuky: žák v terénu zhodnotí význam rostlin, hub, živočichů, uvede př́klady výskytu organismů v určitém prostředí a vztahy mezi nimi, a to včetně různých lidských alergií či nemocí atd.; 
- provázanost přípravy, realizace i hodnocení učiva a prostředí; využití prostředí venku jako modelu pro vysvětlení jevů.

Celkově lze interpretovat, že výroky učitelů při druhém sběru dat ukazují, že vztah $\mathrm{k}$ výuce mimo třídu se mění, učitelé fenomén promýšlejí a následně reflektují s přesvědčením, že má smysl: „Zahrada je inspirativní i při výuce o bakteriích a virech, má smysl být s žáky venku, když to promyslím, venku se dá pokaždé najít něco jako př́íklad k vyučovanému tématu..."

Data žáků byla poprvé získávána bezprostředně po návratu z výuky venku. Otázku pokládala osobně badatelka, žáci odpovědi psali anonymně na papír. Jedna skupina - žáci šestého ročníku - výuku př́rodopisu venku realizovala s učitelem poprvé. Vydali se na hodinovou terénní výuku a hned poté byli požádání o její reflexi. Výroky (reflexe vztahu k výuce venku) byly utříděny do dvou polárních skupin, na klady a zápory rozpoznatelné ve výrocích. Tuto interpretaci v procesu zpracování dat navrhli respondenti sami. U této třídy zápory výuky venku významně převažovaly nad klady.

Druhou skupinu tvořili žáci ročníku osmého. S učitelkou vycházeli ve výuce ven častěji, do té doby asi šestkrát ročně, i když většinou s cílem přímého pozorování či poznávání konkrétních prrírodnin a organismů, přičemž tyto hodiny byly vedeny jako opakovací a fixační pro již zvládnuté učivo. Polarita výroků vyjadřující vztah $\mathrm{k}$ výuce mimo třídu byla i zde viditelná. Zde byly klady a zápory co do výčtu vyrovnány.

V obou třídách byly klady i zápory formulovány téměř shodně, jen frekvence jednotlivých odpovědí se lišila. Jednotlivé výroky byly sdruženy do kategorií, které jsou uvedeny dle zastoupení výroků:

- zápory výuky venku: fyzická námaha; zdržování; přezouvání a oblékání; náročný pohyb; pocení; spěch; zima; vyrušování - problém soustředit se; mokro pod nohama, bahno, pošpinění obuvi a oděvu; učitele není slyšet; moc podnětů najednou; nevím vůbec, o čem to bylo; nebylo kam na WC; ztížené podmínky pro zápis informací; nemožnost dohledat zdroje - není učebnice; hůř se mi to pamatuje; všichni mluví, je tam hluk; chaos - stresuje mě to; nemám klid na myšlení atd.;

- klady: provětráme se; dýcháme čerstvý vzduch; o čem se mluví - hned vidím, slyším, cítím a mohu si sáhnout; poznám okolní přírodu; už pojmenuju mraky; změna - nenuda; vím, proč na flyši rostou tyto rostliny a k nim se stahují tahle zvířata; vím, co je pyl, viděl/a jsem ho (hurá!); viděl/a jsem klíště, buk, chrpu atd. 
V rámci druhého sběru dat u žáků, poté, co jejich vyučující absolvovali školení v rámci výše uvedených institucí, se ve tř́dě bývalých šestáků, tehdy aktuálně sedmáků, poměr kladů a záporů výuky v terénu pozměnil ve prospěch kladů. Žáci již nepoukazovali na jakýkoliv organizační chaos, zmatek či problémy napřs s tím, že by učitele neslyšeli nebo že by měli ztížené podmínky pro zápis poznámek. $V$ rozhovoru $v$ rámci třídy, za přítomnosti učitele, bylo zjišt'ováno, jaká v té věci proběhla opatření.

Zjištění bylo následující: učitel připravuje žákủm do každé výuky venku pracovní list se základní osnovou výuky, s cílem a podmínkami, za kterých žáci naplní své učení. Pracovní list jim poskytuje na počátku výuky na pevné psací podložce, zájemcům ho pošle přímo do mobilního telefonu a respektuje to, že si žáci provádí záznam výuky dle svého uvážení.

Ve třídě žáků původně osmého ročníku, ted' devátáků, se také ukázal mírný posun ke kladné evaluaci výuky, zde hlavně ve smyslu:

Paní učitelka má ted' pořád nové nápady [...] je to zábavné, užíváme si to. Pracujeme venku s mikroskopy, máme sady na odběry vzorků [...] jsme jako vědci. Sčítáme rostliny (ptáky, hmyz, obojživelníky) pro celostátní databázi BioLib a BioLog a můžeme je tam zapisovat pod svými jmény, jsme fakt jako vědci.

Nicméně i výše deklarované zápory výuky venku byly zachovány, jen ve výrazně nižší frekvenci než při prvním sběru dat (přesuny, nepohodlí, nejistota z prostředí atd.).

Z dat získaných u obou testovaných skupin, učitelů i žáků, vyplynulo, že výuka př́rodopisu venku byla pozitivněji hodnocena poté, co učitelé absolvovali (nějaký) vzdělávací kurz o výuce v př́rodě. Učitelé uvádějí, že zde získali praktické náměty a inspiraci zejména pro konkrétní činnosti, popř. organizaci výuky, a sami se pak při př́ipravě výuky mohli soustředit na učivo a výstupy výuky (cíle).

Aktivity a kurzy, které učitelé absolvovali (výčet viz výše), byly jimi reflektovány jako př́nosné, což z dat vyplynulo:

Bez koordinátorského studia bych nevěděl, která bije [...] nikdy by mě nenapadlo, že to může být tak př́nosné [výuka venku] ted' mi to dává smysl [...].

Je to těšší než příprava na výuku ve třídě, ale u konkrétního učiva to dává smysl [...] budu to využívat a budu chodit na další školení.

Globe je úžasný projekt, zájem o př́rodovědný seminář raketově vystartoval, děckám už ani nevadí to nepohodlí. 


\section{Diskuse}

Téma pro tuto studii původně vzniklo $\mathrm{v}$ rámci jiného výzkumného šetření a relativně akutně vyplynulo z praxe, z terénu. Prvním impulsem bylo emotivně vyjádřené rozhořčení učitelů přírodopisu, kteří vyslovili obavy z (ná)tlaku veřejnosti na vedení škol a následně i na ně, aby přesunuli výuku přírodopisu na druhém stupni ZŠ z vybavených tříd a laboratoří do terénu, s vágní argumentací, že děti dnes pořád sedí zavřené v budovách a u počítačů a mělo by se to změnit. Tito učitelé se ale na výuku $v$ prŕrodě necítili připraveni, obávali se přesunu z (podle nich) relativně kontrolovatelného prostředí třídy do neovladatelného a nekontrolovatelného prostředí př́rody. Nerozpoznávali smysl této výuky, byt' sami terénním výcvikem v rámci oboru prošli.

Ukázalo se, že významný vliv mělo na jejich reflexi výuky mimo třídu to, zda na ni byl učitel připraven a zda zvládl zejména její organizaci ve smyslu př́pravy i realizace a následného hodnocení. Naopak zajedno byli učitelé v tom, že pokud výuka nebude směřovat ke konkrétním vzdělávacím cílům, ale půjde jen o výše deklarovaný zážitek, tak smysl nemá a patři do volnočasových aktivit.

Významnou roli sehrálo studium k výkonu specializovaných činností v oblasti environmentální výchovy učitelů. Už v době realizace studia se před očima měnil deklarovaný názor učitelů na výuku venku. Bylo průběžně pozorovatelné, jak reflektují osobní zkušenosti se zaváděním přístupů a metod výuky venku, které v rámci studia nabyli, jak teorii uvádějí ve svých školách v praxi a následně o tom diskutují a analyzují v rámci společných setkání.

Jednoznačně se projevilo, že zvýšení sebejistoty učitelů při výuce venku, a právě hledání řešení hledání řešení, jak venku vyučovat (oproti původnímu odmítání výuky venku), se projevilo zvýšením subjektivně hodnocené kvality alespoň některé části výuky. Nejvýrazněji se to projevilo v oblasti organizace výuky, což dokládají data z druhé sady dotazování. Ke změně došlo také v tom, jak výuku reflektovali sami učitelé, což také vyplývá z druhé sady dotazování, ve kterém byl pozorovatelný odklon od vágního deklarativního hodnocení kladů této výuky (děti budou na vzduchu) směrem ke konkrétním představám, formulacím cílů i výběrům vhodného učiva do terénu.

\section{Závěr}

Předložená studie se zabývá společensky frekventovaným tématem, konkrétně výukou přírodopisu mimo třídu, venku, v přírodě, zde na druhém 
stupni základní školy. Pomocí názorů učitelů a žáků hledá odpovědi na otázku, zda má smysl, aby $\mathrm{v}$ rámci výuky opustili bezpečné a přizpůsobené prostředí školní tř́dy a vyšli do nejistého prostředí ven, do terénu. $\mathrm{Z}$ výzkumu vyplývá, že učitelé reflektují, že ano, ale ne zbrkle a pod tlakem. Vždy jen po př́ípravě, po projednání nejen s žáky a jejich rodiči, ale hlavně po jejich kvalifikované profesní přípravě na změnu prostředí pro výuku. Protože jiné změny by to pro učitele-profesionála nemělo přinést. Jeho práce s obsahy, cíli i výstupy výuky je rámcově shodná ve třídě i v terénu a její výsledky by měly odpovídat naplňování výukových cílů vyplývajících ze školních vzdělávacích programů. Ukázalo se, že názor učitelů na výuku mimo třídu, venku, respektive jejich pojetí výuky konkrétních obsahů př́rodopisu, je možné ovlivnit, jak se projevilo zde, např́íklad v rámci dalšího vzdělávání. To, jak v praxi propojit plnohodnotnou výuku, vybrat a zpracovat smysluplně konkrétní obsahy, zvolit metody a formy práce vhodné mimo třídu, venku, do terénu a vše zorganizovat ke spokojenosti žáků i své, je pedagogické mistrovství, kterému se i učitel musí (na)učit.

\section{Literatura}

Blažek, R., Janotová, Z., Potužníková, E., \& Basl, J. (2018). Mezinárodní šetření PISA 2018. Národní zpráva. Česká školní inspekce.

Dočekal, V. (2012). Prožitkové, zážitkové, nebo zkušenostní učení? e-Pedagogium, 12(1), 9-17.

Frankl, V., E. (2006). Lékařská péče o duši: základy logoterapie a existenciální analýzy. Cesta.

Jáč, M., Kopecká, J., Morris, M., \& Vránová, O. (2019). Didaktické kazuistiky výuky př́rodopisu a biologie. Univerzita Palackého v Olomouci.

Jirásek, I. (2016). Doxa a epistémé zážitkové pedagogiky. Pedagogika, 66(2), 154-178.

Kalhous, Z., \& Obst, O., et al. (2002). Školní didaktika. Portál.

Kotá, J. (2012). Traktát o vybraných problémech teorie a praxe v oblasti pedagogických věd. Pedagogická orientace, 22(3), 336-352.

Kropáč, J., \& Kropáčová, J. (2006). Didaktická transformace pro technické předměty. Univerzita Palackého v Olomouci.

Lukášová, H. (2015). Učitelské sebepojetí a jeho zkoumání. UTB Zlín.

Maňák, J., \& Švec, V. (2003). Výukové metody. Paido.

Mareš, J. (1990a). Učitelovo pojetí výuky (1. díl). Výchova a vzdělání, 1(2), 31-33.

Mareš, J. (1990b). Učitelovo pojetí výuky (2. díl). Výchova a vzdělání, 1(3), 51-54.

Mareš, J., Slavík, J., Svatoš, T., \& Švec, V. (1996). Učitelovo pojetí výuky. Masarykova univerzita.

Obst, O. (2017). Obecná didaktika. Univerzita Palackého v Olomouci.

Papáček, M., Čížková, V., Kubiatko, M., Petr, J., \& Závodská, P. (2015). Didaktika biologie: didaktika v rekonstrukci. In I. Stuchlíková \& T. Janík (Eds.), Oborové didaktiky: vývoj-stav-perspektivy (s. 225-257). Masarykova univerzita. 
Plán hlavních úkolů České školní inspekce na školní rok 2018/2019. (2018). [online]. ČŠI. https://www.csicr.cz/getattachment/cz/Dokumenty/Plan-hlavnich-ukolu/20182019-Plan-hlavnich-ukolu-Ceske-skolni-inspekc/Plan-hlavnich-ukolu-Ceske-skolniinspekce_2018-2019.pdf.

Přehled šablon a jejich věcný výklad, př́loha č. 3. (2018). [online]. NIDV. https://www.nidv.cz/ old/strategicke-rizeni/296-sablony/sablony-ii/1319-sablony-ii-ms-zs-sd-sk-zus-svc.

Rámcový vzdělávací program pro základní vzdělávání. (2017). [online]. MŠMT. https://www. msmt.cz/file/43792/.

Slavík, J., \& Čapková, D. (1994). Reflexe učitelské profese: divadlo, dílna a těžká život v pojetí výuky. Pedagogika, 44(4), 377-388.

Strouhal, M. (2013). Teorie výchovy: $k$ vybraným problémům a perspektivám jedné pedagogické disciplíny. Grada.

Ševčíková, J., \& Plischke, J. (2020). Vybrané aspekty profesního přesvědčení začínajících učitelů. e-Pedagogium, 20(1), 7-15.

Štech, S. (1994). Co je to učitelství a lze se mu naučit? Pedagogika, 44(4), 310-320.

Štech, S. (2000). Křivá huba, nebo křivé zrcadlo. (O hříchu podvodných interpretací). Pedagogika, 50(2), 117-120.

Šíp, R. (2019). Proč školství a jeho aktéři selhávají. Masarykova univerzita.

Švaříček, R. (2007). Biografický design. In R. Švaříček \& K. Šed'ová, et al., Kvalitativní výzkum v pedagogických vědách (s. 126-141). Portál.

Švec, V. (1997). Sebereflexe jako nástroj profesionálního (sebe)rozvíjení začínajících učitelů. Pedagogická orientace, 7(3), 2-13.

Vaštatková, J., \& Prášilová, M. (2007). Česká škola = učící se škola. Pedagogická orientace, 17(1), 5-11.

\section{Autor}

PhDr. Jaroslava Ševčíková, Ph.D., Univerzita Palackého v Olomouci, Pedagogická fakulta, Ústav pedagogiky a sociálních studií, Žižkovo nám. 5, 77900 Olomouc, e-mail: jaroslava.sevcikova01@upol.cz

\section{Teaching in nature: A passing trend or meaningful teaching?}

Abstract: The study deals with a socially frequent topic, parallel to the ongoing
professional discussion, namely the teaching of biology at lower secondary schools
outdoors. We examine the relationship of teachers and pupiks to this type of activity.
The qualitative research involved 29 science teachers from 27 primary schools, and
38 pupils from two classes of different schools. Data collection took place using the
method of autonomous writing in which the individual describes and evaluates their
experience without the intervention of the researcher and, in addition, through
interviews on the topic. The research took place in a natural environment, in 
schools. The data are the result of subjective reflection by individuals. The data were processed using content analysis and coded. The texts were divided into meaning fragments and these were then grouped into categories. Subsequent interpretation was realized through collaborative accounts. The results show that teaching natural sciences outdoors makes sense to the participating teachers and students only if they identify with it and are prepared for it; if it is done well not only professionally in terms of content, but also in terms of organization.

Keywords: teaching, instruction, learning, biology, lower secondary school 